\title{
PELAKSANAAN BUDAYA HUKUM HAKIM DAN ADVOKAT DALAM KAITANNYA DENGAN PENEGAKAN HUKUM
}

\author{
Hulman Panjaitan \\ hulman234@yahoo.com \\ Universitas Kristen Indonesia, Jakarta, Indonesia
}

\begin{abstract}
Legal culture is a very important element and priority is a concern in relation to law enforcement, that's not limited to the implementation of the legal culture of judges and advocates as part of law enforcement, the execution and implementation of the legal culture of each law enforcement apparatus, including judges and advocates have not become a serious concern, what has become a code of ethics as a guideline for behaving for judges and advocates has not inspired and integrated in the life and behavior of a judge and advocate in carrying out their duties and responsibilities, therefore, for enforcement of the law and justice, presumably this legal culture as one of the most important elements in the legal system must befullyapplied and implemented by each law enforcement apparatus.
\end{abstract}

Keywords : culture; implementation; ethics.

\section{Pendahuluan}

Pada dasarnya, hukum tidak hanya sekedar indah diatas kertas sebagaimana dituangkan dalam berbagai bentuk peraturan perundang-undangan, melainkan hukum hendaknya dilihatsebagai suatu gejala yang dapat diamati dalam kehidupan masyarakat melalui pola tingkah laku. Hukum adalah merupakan fenomena social dalam masyarakat. Hal ini berarti, keberadaan hukum sebagai suatu fenomena social dalam masyarakat sangat dipengaruhi oleh factor-faktor non hukum seperti nilai, sikap dan pandangan masyarakat serta kebiasaan yang dalam pengertian luas disebut sebagai budaya hukum atau kultur. Adanya kultur atau budaya hukum inilah yang menyebabkan perbedaan penegakan hukum diantara dan sesama masyarakat.

Budaya hukum itu sendiri dapat dibedakan menjadi :

a. Budaya Hukum internal.
Budaya hukum internal merupakan budaya hukum dari warga masyarakat yang melaksanakan tugas-tugas hukum secara khusus, seperti budaya hukum advokat, polisi, hakim, jaksa dan sebagainya.

b. Budaya Hukum eksternal.

Budaya hukum eksternal merupakan budsaya hokum masyarakat pada umumnya, seperti, budaya hukum etnis suatu bangsa, seperti Jawa, Sunda, Batak, Amerika, Singapore dan sebagainya.

Berbicara mengenai budaya hukum, baik internal maupun eksternal tidaklah sama satu sama lain. Selalu terdapat perbedaan sebagaimana dirumuskan diatas yang diakibatkan perbedaan watak (karakter), streotip etnik (ciri has suatu bangsa) dan pengalaman pada masa lampau. Misalnya, budaya hukum para 
penegak hukum ${ }^{1}$ seperti Jaksa, Hakim, Advokat Pengacara. Para pemegang profesi hukum ini mempunyai budaya hukum yang berbeda, baik secara substansial maupun dalam praktek implementasinya dalam masyarakat, khususnya dalam kaitan dengan penegakan hukum.

Perbedaan dan keberagaman budaya hukum seperti ini mengakibatkan masing-masing pihak memiliki pandangan sendiri-sendiri dalam menyikapi suatu permasalahan hukum atau kasus tertentu (in case). Penanganan suatu kasus akan lebih baik dan sempurna, bilamana diantara dan sesama penegak hukum terdapat persamaan pandangan dan sikap terhadap suatu perkara tertentu. Substansi dan implementasi budaya hukum hakim sangat dipengaruhi oleh fungsinya dan tugasnya sebagai penegak hukum dalam memeriksa, mengadili dan memutus suatu perkara. Sedangkan budaya hukum advokat sangat dipengaruhi oleh fungsi dan tugasnya sebagai advokat yang memberikan bantuan hukum dan pembelaan kepada seorang penyakitan di bidang hukum yang disebut dengan klien.

Tidak jarang ditemukan, baik melalui media cetak maupun media elektronik, adanya perbedaan paradigma antara hakim dan advokat dalam menangani dan menyelesaikan suatu permasalahan. Perbedaan ini sangat menentukan penegak

1 Bagir Manan, dalam makalahnya yang dimuat dalam Majalah Varia Peradilan, Tahun ke XXII No. 261, Agustus 2007, halaman 6 mengemukakan bahwa dalam ajaran tradisional (demikian pula ungkapan sehari-hari), penegak hukum diartikan sebagai lingkungan jabatan (ambten) atau pejabat (ambtsragers) yang menjalankan tugas dan wewenang mempertahankan hukum (handhadaving van het recht) terhadap seseorang atau sekelompok orang yang melanggar hukum atau melakukan perbuatan melawan hukum atau pengingkaran suatu perikatan hukum. hukum dan bekerjanya hukum dalam masyarakat, khususnya penerapan suatu peraturan perundang-undangan khusus di bidang tertentu yang berkaitan dengan suatu perkara yang sedang diselesaikan. Posisi dan tempat duduk hakim dalam proses persidangan yang berada diatas sedangkan posisi dan tempat advokat yang berada dibawah secara psikologis mempengaruhi penerapan atau implementasi budaya hukum yang sangat berbeda, pada hal sesungguhnya dengan peraturan perundang-undangan yang ada, antara hakim dan advokat adalah samasama aparat penegak hukum. ${ }^{2}$

Penegakan hukum merupakan suatu system sebagai serangkaian aktivitas kehidupan hukum mulai dari perencanaan, pembentukan, penegakan atau pelaksanaannya termasuk evaluasi pelaksanaannya. Penegakan hukum pada hakekatnya merupakan interaksi antara berbagai perilaku manusia yang mewakili kepentingan-kepentingan yang berbeda dalam bingkai aturan yang telah disepakati bersama. Oleh karena itu, penegakan hukum tidak semata-mata dianggap sebagai suatu proses menerapkan hukum sebagaimana pendapat kaum legalistic. Melainkan, proses penegakan hukum mempunyai dimensi dan aspek yang lebih luas daparipada hal tersebut, karena dalam terminologi penegakan hukum akan melibatkan dimensi perilaku manusia atau budaya hukumnya.Dengan pemhaman tersebut, maka dapat diketahui bahwa persoalan-persoalan hukum yang akan selalui menonjol dalam kaitan dengan

\footnotetext{
2 Pasal 5 Undang Undang Nomor 18 Tahun 2003 tentang Advokat menentukan bahwa advokat berstatus sebagai penegak hukum, bebas dan mandiri yang dijamin oleh hukum dan peraturan perundang-undangan.
} 
penegakan hukum adalah persoalan law in action dan bukan pada law in the books.

Pada prinsipnya, penegakan hukum harus dapat memberikan manfaat bagi banyak orang atau berdaya guna, namun disamping itu, masyarakat juga mengharapkan adanya penegakan hukum untuk mencapai suatu keadilan. Kendatipun demikian, tidak dapat dipungkiri bahwa apa yang dianggap berguna (secara sosiologis) adalah belum tentu adil, demikian sebaliknya, apa yang dirasakan adil (secara filosofis) adalah belum tentu berguna bagi masyarakat. Adapun yang merupakan pokok permasalahan yang akan dibahas dalam penulisan karya ilmiah ini adalah bagaimanakah pelaksanaan atau implementasi budaya hukum hakim dan advokat dalam praktek penegakan hukum.

\section{Pembahasan}

\section{Kerangka Teoritis tentang Budaya Hukum}

Tb Ronny Rahman Nitibaskara ${ }^{3}$ mengemukakan bahwa kajian mengenai budaya hukum ternyata relatif luas sehingga dapat dikatakan satu pendekatan saja mungkin tidak memadai. Oleh karena itu, juga dapat dimaklumi bahwa legal culture sulit didefinisikan. Beliau secara sederhana merumuskan budaya hukum adalah sub-sub budaya yang bertalian dengan penghargaan dan sikap tindak manusia terhadap hukum sebagai realitas social.

Berdasarkan rumusan tersebut, selanjutnya dikemukakan variabel-variabel dari budaya hukum adalah :

1. Sub budaya

${ }^{3}$ Tb Ronny Rahman Nitibaskara, Perangkap Penyimpangan dan Kejahatan, Teori Baru Dalam Kriminologi, (Jakarta : Yayasan Pengembangan Kajian Ilmu Kepolisian (YPKIK), 2009), halaman 56.
Legal culture merupakan sub unsur budaya, yaitu yang berinduk pada unsur budaya normatif yang bersifat universal.

2. Manusia

Unsur itulah yang menjadi sentralitas budaya hukum karena berperan sebagai pembentuk dan pendukung serta pengubahnya sekaligus bahkan penilai baik buruknya budaya hukum orang lain. Oleh karena itu, unsur itu tidak dapat dilepaskan dari unsur ketiga berikut.

3. Penghargaan dan sikap tindak

Variabel ini merupakan unsur yang mendorong kelahiran perilaku yang dapat disebut budaya hukum.

4. Hukum sebagai realitas social

Dalam batasan ini, hukum tidak diperkenankan untuk dilepaskan dari realitas yang berkembang pada suatu periode tertentu.

RM. Panggabean menyatakan bahwa pembahasan mengenai budaya hukum secara konseptual lebih-lebih dikaitkan dengan budaya hukum hakim dalam menjalankan fungsinya merupakan hal yang baru dibicarakan di Indonesia. Berbeda dengan negara-negara yang sudah maju dan memiliki peradaban yang tinggi, budaya hukum sudah lama dibahas dan merupakan bagian yang tidak terpisahkan dari sistem hukum. ${ }^{4}$ Sebagaimana pendapat Satjipto Rahardjo dalam makalahnya yang berjudul Pembangunan Budaya Hukum Pada Pelita VII dan disampaikan dalam seminar Kepolisian Negara Republik Indonesia tentang Persfektif Pembangunan

${ }^{4}$ RM. Panggabean, Budaya Hukum Hakim, Dibawah Pemerintahan Demokrasi dan Otoriter (Studi Tentang Putusan-Putusan Mahkamah Agung RI, 1950-1965), (Jakarta : Pusat Studi Hukum Ekonomi Universitas Indonesia, Fakultas Hukum, 2008), halaman 1. 
Bidang Hukum Pada Pelita VII, Jakarta, 18 Juni 1996, yang dikutif RM. Panggabean bahwa sejak tahun 60-an pelan-pelan budaya hukum mulai diakui sebagai unsur konstitutif yang membentuk system hukum, disamping unsur-unsur substansi dan struktur. $^{5}$

Sebagaimana dikemukakan

Lawrence M. Friedman bahwa dalam suatu system hukum terdapat 3 (tiga) elemen, yaitu : (1) Struktur hukum (structure), (2) Materi hukum (substance), (3) Budaya hukum (legal culture). Elemen yang ketiga yaitu budaya hukum dirumuskan berupa sikap masyarakat terhadap hukum dan system hukum, kepercayaan mereka, nilainilai yang mereka anut, ide-ide dan pengharapan mereka terhadap hukum. Dengan kata lain, budaya hukum adalah iklim dari pemikiran social dan kekuatan social (the cilamte of social thought and social force) yang menentukan bagaimana hukum digunakan (used), dihindari (avoid) atau disalah gunakan (abused). Bagaimana peranan hukum dalam masyarakat, apakah hukum itu hanya sebagai alat untuk menjaga harmoni, ketertiban dan stabilitas atau hukum itu berisi perlindungan terhadap individu-individu. Jadi ke dalam komponen tersebut adalah kepercayaan terhadap nilai (value), idea tau gagasannya dan harapan-harapannya. Gagasan-gagasan dan opini yang harus dimengerti sebagai hal yang berhubungan dengan perkembangan proses hukum. ${ }^{6}$

Apabila substansi dan struktur hukum menyangkut hal-hal yang eksternal, maka budaya hukum bersifat internal. Budaya hukum dimulai dari nilai-nilai, sikap, moral, kemudian diwujudkan di dalam perilaku hukum, disamping itu, budaya

\footnotetext{
${ }^{5}$ Loc.cit

${ }^{6}$ Ibid, halaman 17.
}

hukum mempunyai kelebihan, mampu menarik perhatian orang terhadap nilai-nilai yang terkait dengan hukum dan proses hukum.

Menurut Masaji Chiba sebagaimana dikutif RM. Panggabean, budaya hukum tidak hanya keyakinan dan nilai-nilai empiris yang dinyatakan secara tidak jelas mengenai hukum sebagaimana sering digunakan dalam budaya politik, tetapi merupakan fenomena budaya lain yang secara khusus berkaitan dengan hukum, antara lain nampak dalam praktek-praktek di bidang hukum, tradisi-tradisi, dalil-dalil hukum (legal postulate), komponenkomponen hukum, budaya hukum yang nyata, symbol-simbol hukum dalam arti yang lebih luas. ${ }^{7}$

Keseluruhan proses pembentukan budaya hukum memiliki keterkaitan dengan dimensi budaya tertentu. Sebagaimana disampaikan Tb Ronny Rahman Nitibaskara, Edward T. Hall membagi dimensi budaya sebagai berikut : 8

1. Monochronics vs polychronics

Mengandung arti, focus tidaknya perhatian dalam melakukan pekerjaan, baik waktu maupun jumlah pekerjaannya. Monochronics adalah budaya yang focus hanya pada satu waktu atau jenis pekerjaan tertentu. Dalam arti, konsentrasi cukup ditujukan pada satu jenis pekerjaan pada satu waktu. Sedangkan polychronics adalah budaya yang menganut prinsip untuk mengerjakan beberapa pekerjaan sekaligus dalam satu waktu, berlawanan dengan monochronics.

2. Space jauh vs space dekat

\footnotetext{
${ }^{7}$ Ibid, halaman 44.

8 Tb. Ronny Rahman Nitibaskara pada Kuliah Program Doktoral Ilmu Hukum Universitas Krisnadwipayana, Jakarta, pada hari Sabtu, 31 Januari 2015.
} 
Secara sederhana, space jauh biasa diartikan kaku atau jauh dari masyarakat dan sesama. Sedangkan space dekat dikenal sebagai lebih fleksibel sehingga kebalikan daripada space jauh.

3. High context vs low context

Hight context dikenal tertutup atau implisit dan kurang terbuka dalam memberikan akses informasi. Sedangkan low context adalah sebaliknya, lebih terbuka dan lebih eksplisit.

Di lain pihak, Hofstede membagi dimensi budaya sebagai berikut :

1. High power distance vs low power distance

Dimensi budaya seperti ini menunjukkan kemampuan untuk menempatkan diri dalam hierarki social yang dipengaruhi factor kekuatan jabatan, politik, uang atau kekuasaan.

2. Uncertainty avoidance (penghindaran ketidak pastian)

It deals with a society's tolerance for uncertainty and ambiguity. Mengandung arti bahwa dimensi budaya ini berkaitan dengan toleransi masyarakat terhadap suatu ketidak pastiuan dan ambiguitas atas situasi dan kondisi yang terjadi. Dimensi budaya ini terbagi menjadi low uncertainty avoidance (budaya penmghindaran ketidak puasan rendah) dan high uncertainty avoidance (budaya penghindaran ketidak puasan yang tinggi).

3. Short and long term orientation

Dimensi budaya ini merupakan suatu orientasi jangka pendek dan orientasi jangka panjang yang dijadikan sebagai ukuran terhadap keberlangsungan suatu profesi.
Kenyataan perbedaan paradigma diantara para penegak hukum sebagaiman diuraikan sebelumnya, memiliki hubungan yang erat dengan dimensi-dimensi budaya tersebut diatas. Hal tersebut secara langsung maupun tidak langsung akan melandasi cara masing-masing dalam memandang dan menyikapi perbuatan yang dikategorikan sebagai suatu permasalahan hukum sesuai dengan budaya hukum yang dianutnya.

2. Pelaksnaan dan Implementasi Budaya Hukum Hakim dan Advokat Dalam Praktek Penegakan Hukum

Soedjono Dirdjosiswono mengemukakan bahwa penegakan hukum (law enforcement) merupakan rangkaian proses untuk menjabarkan nilai-nilai, ide, cita dan selanjutnya menjadi tujuan hukum. Cita hukum atau tujuan hukum membuat nilai-nilai moral, yaitu keadilan (rechtsvoordigheid), kepastian hukum (rechtszekerheid) dan kemanfaatn (doelmatigheid). ${ }^{9}$

Penegakan hukum adalah proses dilakukannya upaya untuk tegaknya atau berfungsinya norma-norma hukum secara nyata sebagai pedoman perilaku dalam lalu lintas atau hubungan-hubungan hukum dalam kehidupan bermasyarakat dan bernegara. Ditinjau dari sudut subjeknya, penegakan hukum itu dapat dilakukan oleh subjek yang luas dan dapat pula diartikan sebagai upaya penegakan hukum oleh subjek dalam arti yang terbatas atau sempit. Dalam arti luas, proses penegakan hukum melibatkan semua subjek hukum dalam setiap hubungan hukum. Siapa saja yang menjalankan aturan normatif atau melakukan sesuatu atau tidak melakukan

\footnotetext{
9 Soedjono Dirdjosiswono, Pengantar IImu Hukum, (Jakarta : CV. Rajawali, 1984), halaman 127.
} 
sesuatu dengan mendasarkan diri pada norma aturan hukum yang berlaku, berarti dia menjalankan atau menegakkan aturan hukum. Dalam arti sempit, dari segi subjeknya, penegakan hukum itu hanya diartikan sebagai upaya aparatur penegak hukum tertentu untuk menjamin dan memastikan bahwa suatu aturan hukum berjalan sebagaimana seharusnya. Dalam memastikan tegaknya hukum itu, apabila diperlukan, aparatur penegak hukum itu diperkenankan untuk menggunakan daya paksa.

Pengertian penegakan hukum juga dapat ditinjau dari segi objeknya, yaitu dari segi hukumnya. Dalam hal ini, pengertiannya juga mencakup makna yang luas dan sempit. Dalam arti luas, penegakan hukum mencakup pula nilai-nilai keadilan yang terkandung di dalamnya bunyi aturan formal maupun nilai-nilai keadilan yang hidup dalam masyarakat. Tetapi dalam arti sempit, penegakan hukum itu hanya menyangkut penegakan peraturan yang formal dan tertulis saja. Karena itu, penerjemahan perkataan law enforcement ke dalam bahasa Indonesia dengan mengartikannya sebagai penegakan hukum dalam arti luas dan dapat pula digunakan istilah penegakan peraturan dalam arti sempit.

Satjipto Rahardjo mengemukakan penegakan hukum adalah kegiatan menyerasikan hubungan nilai-nilai yang terjabarkan dalam kaidah-kaidah, pandangan-pandangan yang mantap dan mengejawantahkannya dalam sikap, tindak sebagai serangkaian penjabaran nilai tahap akhir untuk menciptakan kedamaian pergaulan hidup. ${ }^{10}$ Karena itu, tegaknya

10 Satjipto Rahardjo, Penegakan Hukum : Suatu Tinjauan Sosiologis, (Yogyakarta : Genta Publishing, 2009), halaman vii. hukum dapat ditandai oleh beberapa faktor yang saling terkait sangat erat, yaitu :

1. Hukum dan aturannya sendiri sehingga diperlukan adanya keserasian antara peraturan perundang-undangan yang ada.

2. Fasilitas pelaksanaan hukumnya yang memadai, sebab sering sekali hukum sulit untuk ditegakkan bahkan tak tertangani karena fasilitas untuk menegakkannya tidak memadai ataupun tidak tersedia.

3. Kesadaran dan kepastian hukum serta perilaku masyarakat itu sendiri.

4. Mental aparat penegak hukum. Dalam hal ini adalah pelaku hukum secara langsung seperti polisi, jaksa, hakim dan advokat dan sebagainya karena pada dasarnya penegakan hukum sangat tergantung pada mentalitas para aparatur penegak hukumnya.

Dari uraian tersebut, terlihat bahwa penegakan hukum selain ditentukan oleh aturan-aturan hukumnya sendiri, maka fasilitas, mentalitas para aparat penegak hukum, termasuk hakim dan advokat adalah sangat menentukan, termasuk pula factor kesadaran dan kepatuhan masyarakat, baik secara personal maupun dalam komunitas sosialnya masing-masing. Pada akhirnya kembali kepada unsur manusianya (budaya) juga yang menentukan corak yang sebenarnya. Sehingga adanya hukum yang baik dan benar tidak otomatis menjamin kehidupan masyarakat yang baik dan benar. Adanya polisi, jaksa, hakim dan advokat sebagai penegak hukum langsung dan formal belumlah menjamin tegaknya hukum dan berlakunya rule of law. Analognya, adanya parlemen sekalipun dipilih melalui pemilihan umum dengan ongkos (cost) yang besar belum otomatis, demokratis tumbuh baik dan sempurna. Disamping itu perlu 
juga dipikirkan sarana apa saja yang perlu dibutuhkan agar peraturan hukum itu dapat dijalankan dengan baik. Kesadaran hukum dapat juga ditingkatkan dengan cara memberi contoh untuk masyarakat melalui peranan para penegak hukum, terutama hakim dan advokat melalui pelaksanaan dan implementasi budaya hukumnya. Hal ini dimungkinkan mengingat masyarakat kita masih bersifat paternalistic. Jika semua factor tersebut diatas dapat dilaksanakan dengan baik, tentunya peraturan hukum akan dapat ditegakkan karena kesadaran hukum masyarakat sudah dibina semikian rupa sehingga dapat memperkecil kemungkinan terjadinya penyimpangan tingkah laku yang tidak sesuai dengan hukum dan/atau peraturan tidak terulis lainnya, termasuk kode etik bagi masingmasing profesi hukum hakim dan advokat.

Mengingat secara substansial terdapat perbedaan budaya hukum hakim dan advokat, maka dalam kaitannya dengan penegakan hukum, pelaksanannya adalah sangat berbeda. Budaya hukum hakim dalam penegakan hukum dilaksanakan sesuai dengan tugas dan fungsinya untuk memeriksa, mengadaili dan memutus suatu perkara. Dalam perkara pidana, hakim berada ditengah diantara Jaksa Penuntut Umum dan Advokat atau Penasehat Hukum. Hakim memainkan peran sebagai pemutus dan memberikan pertimbangan berdasarkan fakta dan bukti-bukti di persidangan yang bersumber dari pekerjaan Jaksa Penuntut Umum dan Penasehat Hukum. Demikian dalam perkara perdata, hakim memainkan peran untuk memutus dalil-dalil diantara penggugat dengan tergugat berdasarkan bukti dan fakta-fakta yang diperoleh melalui persidangan.

Dalam praktek penegakan hukum, pelaksanaan budaya hukum hakim dan advokat dibatasi dengan rambu-rambu kode etik profesi masing-masing yang bersangkutan antara hakim dan advokat.

Pengadilan yang mandiri, netral (tidak memihak), kompeten, transparan, akuntabel dan berwibawa yang mampu menegakkan wibawa hukum, pengayoman hukum, kepastian hukum dan keadilan merupakan condition sine quanon atau persyaratan mutlak dalam sebuah Negara yang berdasarkan hukum. Pengadilan sebagai pilar utama dalam penegakan hukum dan keadilan serta proses pembangunan peradaban bangsa. Tegaknya hukum dan keadilan serta penghormatan terhadap keluruhan nilai kemanusiaan menjadi prasyarat tegaknya martabat dan integritas Negara. Dan hakim sebagai actor utama atau figure sentral dalam proses peradilan senantiasa dituntut untuk mengasah kepekaan nurani, memelihara integritas, kecerdasan moral dan meningkatkan profesionalisme dalam menegakkan hukum dan keadilan bagi rakyat banyak. ${ }^{11}$

Hakim sebagai insan yang memiliki kewajiban moral untuk berinteraksi dengan komunitas sosialnya juga terikat dengan norma-norma etika dan adaptasi kebiasaan yang berlaku dalam tata pergaulan masyarakat, Namun demikian, untuk menjamin terciptanya pengadilan yang mandiri dan tidak memihak, diperlukan pula pemenuhan kecukupan sarana dan prasarana bagi hakim, baik selaku penegak hukum maupun sebagai warga masyarakat.

Beberapa hal yang perlu mendapat perhatian atas materi pengaturan dan pelaksanaan budaya hukum hakim yang

11 Pembukaan Kode Etik dan Pedoman Perilaku Hakim dalam Keputusan Bersama Ketua Mahkamah Agung RI dan Ketua Komisi Yudisial RI No. 047/KMA/SKB/IV/2009, 02/SKB/P.KY/IV/2009 tentang Kode Etik dan Pedoman Perilaku Hakim, tanggal 8 April 2009. 
diatur dalam kode etik dan perilaku hakim adalah :

a. Berperilaku adil.

Seorang yang melaksanakan tugas atau profesi di bidang peradilan yang memikul tanggung jawab menegakkan hukum yang adil dan benar harus selalu berlaku adil dengan tidak membedabedakan orang.

Penerapannya adalah diantaranya hakim harus memberikan keadilan kepada semua orang dan tidak beritikad semata-mata untuk menghukum. Serta pelaksanaan asas audio et alterem partem ${ }^{12}$ dalam hukum acara perdata Indonesia.

b. Berperilaku jujur.

c. Berperilaku arif dan bijaksana

d. Bersikap mandiri

e. Berintegritas tinggi

f. Bertangung jawab

g. Menjungjung tinggi harga diri

h. Berdisiplin tinggi

i. Berperilaku rendah hati

j. Bersikap professional

Advokat sebagai profesi terhormat (officium nobile) yang dalam menjalankan profesinya berada dibawah perlindungan hukum, undang-undang dankode etik, memiliki kebebasan yang didasarkan kepada kehormatan dan kepribadian advokat yang berpegang teguh kepada kemandirian, kejujuran, kerahasiaan dan keterbukaan. Bahwa profesi advokat adalah selaku penegak hukum yang sejajar dengan instansi penegak hukum lainnya, oleh karena itu sama sama lainnya harus saling menghargai antara teman sejawat dan juga

\footnotetext{
${ }^{12}$ Audio et alterem partem adalah asas dalam hukum acara perdata Indonesia yang memberikan hak dan kesempatan yang sama kepada para pihak yang berperkara untuk mempertahankan hak dan kepentingannya masing-masing dalam proses persidangan pengadilan.
}

antara para penegak hukum lainnya. Oleh karena itu, setiap advokat harus menjaga citra dan martabat kehormatan profesi serta setia dan menjungjung tinggi kode etik dan sumpah profesi yang pelaksanananya diawasi oleh Dewan Kehormatan sebagai suatu lembaga yang eksistensinya telah dan harus diakui setiap advokat tanpa melihat dari organisasi profesi yang mana dia berasal dan menjadi anggota yang pada saat mengucapkan sumpah profesinya tersirat pengakuan dan kepatuahnnya terhadap kode etik advokat yang berlaku. ${ }^{13}$

Secara umum, pengaturan kode etik advokat dapat dikelompokka sebagai berikut :

1. Kewajiban advokat

2. Kewajiban advokat kepada masyarakat

3. Kewajiban advokat kepada penagdilan

4. Kewajiban advokat kepada sejawat profesi

5. Kewajiban advokat kepada klien

6. Cara bertindak dalam menangani perkara

Sebagai akhir dari penulisan karya ilmiah ini, akan disampaikan apa yang dikemukakan oleh Achmad Ali bahwa akhirnya agar perilaku aparat penegak hukum, mencakup polisi, pengacara, jaksa dan hakim dapat mengembalikan kepercayaan warga masyarakat, saya menghimbau para penegak hukum dalam menjalankan tugasnya lebih banyaklah bertanya pada hati nurani mereka, ketimbang pada perut mereka. Seperti yang senantiasa saya serukan : "Marilah kita kembalikan hukum kepada akar moralitas dan rilijiusnya. "Bukankah seorang filosof yang bernama Taverne pernah menyatakan bahwa "Berikanlah saya seorang jaksa yang jujur dan cerdas, berikanlah saya seorang

13 Pembukaan Kode Etik Advokat Indonesia, yang disahkan pada tanggal 23 Mei 2002. 
hakim yang jujur dan cerdas, maka dengan undang-undang yang paling burukpun, saya akan menghasilkan putusan yang adil. ${ }^{14}$

Kesimpulan dan Saran

Budaya hukum (culture) merupakan unsur yang sangat penting dan prioritas menjadi perhatian dalam kaitannya dengan penegakan hukum, tidak terbatas kepada pelaksanaan budaya hukum hakim dan advokat sebagai bagian dari penegak hukum.Implementasi dan pelaksanaan budaya hukum masing-masing aparat penegak hukum, termasuk hakim dan advokat belum menjadi perhatian serius. Apa yang menjadi kode etik sebagai pedoman dalam berperilaku bagi hakim dan advokat belum menjiwai dan menyatu dalam kehidupan dan perilaku seorang hakim dan advokat dalam pelaksanaan tugas dan tanggung jawabnya. Oleh karena itu, untuk tegaknya hukum dan keadilan, kiranya budaya hukum ini sebagai salah satu unsur terpenting dalam sistem hukum harus benar-benar diterapkan dan diimplementasikan masing-masing aparat penegak hukum.

14 Tulisan Achmad Ali yang berjudul Ulasan Terhadap Buku Fungsi Mahkamah Agung Dalam Praktik Sehari-hari, dalam Henry P. Panggabean, Fungsi Mahkamah Agung Dalam Praktik Sehari-hari, (Jakarta : Pustaka Sinar Harapan, 2001), halaman xv.

\section{Daftar Pustaka}

Dirdjosiswono Soedjono, Pengantar IImu Hukum, (Jakarta : CV. Rajawali, 1984).

Nitibaskara, Ronny Rahman, Perangkap Penyimpangan Dan Kejahatan, Teori Baru Dalam Kriminologi,(Jakarta : Yayasan Pengembangan Kajian Ilmu Kepolisian, 2009).

Sebuah Pendekatan Kriminolgi, Hukum dan Sosiologi, (Jakarta : Peradaban, 2001)

Panggabean RM, Budaya Hukum Hakim, Dibawah Pemerintahan Demokrasi dan Otoriter (Studi Tentang PutusanPutusan Mahkamah Agung RI, 19501965), (Jakarta : Pusat Studi Hukum Ekonomi Universitas Indonesia, Fakultas Hukum, 2008),

Panggabean Henry $P$, Fungsi Mahkamah Agung Dalam Praktik Sehari-hari, (Jakarta : Pustaka Sinar Harapan, 2001).

Valerie Miller dan Jane Covey, Pedoman Advokasi, Perencanaan, Tindakan dan Refleksi, (Jakarta : Yayasan Obor Indonesia, 2005)

Undang Undang Republik Indonesia Nomoir 18 Tahun 2003 tentang Advokat, (Jakarta : CV. Eko Jaya, 2003

Rahardjo, Satjipto, Ilmu Hukum, (Bandung : Citra Aditya Bhkati, 2001).

----------, Aneka Persoalan Hukum Dan

Masyarakat, (Bandung : Alumni, 1977).

---------, Penegakan Hukum : Suatu

Tinjauan Sosiologis, (Yogyakarta : Genta Publishing, 2009).

Varia Peradilan Tahun XXII No. 261, Agustus 2007.

Pendulum Antinom Hukum, Antologi 70 Tahun Valerine J.L. Kriekhoff, (Yogyakarta : Genta Publishing, 2014) 